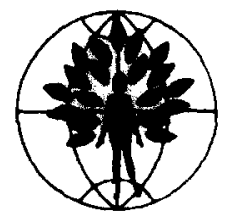

\title{
Obstetrician-gynecologists and the public health
}

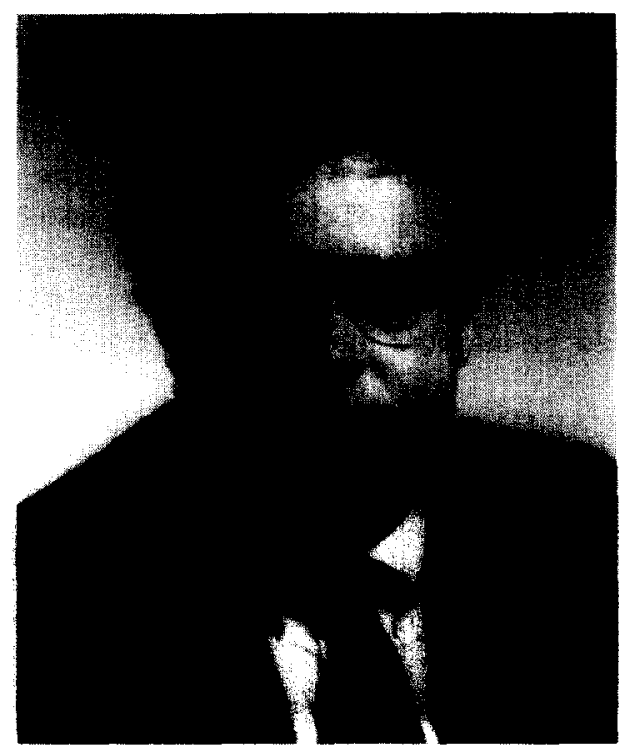

Timothy R.B. Johnson

Bates Professor of Diseases of Women and Children, Chair, Department of Obstetrics and Gynecology,

Research Scientist, Center for Human Growth and Development,

Professor of Women's Studies, University of Michigan, Ann Arbor, Michigan, USA

I am quite encouraged by the increasing involvement of obstetrician/gynecologists in improving women's health. After the wake up call by Allan Rosenfield [1] to refocus on the Maternal aspects of Maternal and Child Health and the recent Safe Motherhood initiatives of WHO and FIGO, major emphasis has been turned towards increasing lifesaving skills of medical personnel and preventing maternal mortalities in the developing world. Programs have been implemented which have redirected resources to provide health care professionals with essentials of obstetric care such as access to blood banking, antibiotics, and rapid surgical management of obstetric complications, including incomplete abortion and obstructed labor.

In this issue, Dr. Mark Pearlman [2] reviews the problem of maternal and fetal death from auto accidents and trauma. In 1992 in the United States, 1 of every 6 deaths among women aged 15-44 was due to accidents, including 1 out of 8 due to motor vehicle accidents. Not only has the incidence of car accidents and massive trauma been increasing in the reproductive age population but with the decrease in other causes of mortality among women, previously under-recognized issues become increasingly important. Disturbing recent reports [3] suggest that maternal mortality is widely under-reported. Undiagnosed ectopic pregnancy and untreated incomplete septic abortion remain important causes of death among women and new attention on domestic violence, homicide and trauma has emphasized hereto under-recognized causes of death of pregnant and non-pregnant women [3-6].

Dr. Pearlman emphasizes the important role 
Table 1

Leading causes of death (women in the United States)

\begin{tabular}{llll}
\hline Ages 13-18 years & Ages 19-39 years & Ages 40-64 years & Ages 65 years and older \\
\hline Motor vehicle accidents & Motor vehicle accidents & Cardiovascular disease & Cardiovascular disease \\
Homicide & Cardiovascular diseases & Coronary artery disease & Coronary artery disease \\
Suicide & Homicide & Breast cancer & Cerebrovascular disease \\
Leukemia & Coronary artery disease & Lung cancer & Pneumonia/influenza \\
& Acquired immunodeficiency & Cerebrovascular disease & Obstructive lung disease \\
& syndrome (AIDS) & Colorectal cancer & Colerectal cancer \\
& Breast cancer & Obstructive pulmonary disease & Breast cancer \\
& Cerebrovascular disease & Ovarian cancer & Lung cancer \\
& Uterine cancer & & Accidents \\
\hline
\end{tabular}

either the United States or internationally. Recently, others have pointed to the role of suicide in the theater of international maternal mortality and recommended an expansion of the conventional definition of maternal mortality [7]. The International Classification of Disease, Ninth Revision (ICD-9) defines maternal death as 'the death of a woman while pregnant or within 42 days of termination of pregnancy, from any cause related to or aggravated by the pregnancy or its management, but not from accidental or incidental causes'.
ICD-10 adds a new category 'pregnancy related death' defined as 'the death of a woman while pregnant or within 42 days of termination of pregnancy, irrespective of cause of death'. The Centers for Disease Control, the American College of Obstetricians and Gynecologists and the Maternal Mortality Committee of the Massachusetts Medical Society have long used more inclusive criteria $[3,8]$.

A simple broad definition of maternal mortality should be adopted internationally now: Maternal

Table 2

Leading causes of morbidity (women in the United States)

\begin{tabular}{|c|c|c|c|}
\hline Ages $13-18$ years & Ages $19-39$ years & Ages $40-64$ years & Ages 65 years and older \\
\hline $\begin{array}{l}\text { Nose, throat, and upper } \\
\text { respiratory conditions }\end{array}$ & $\begin{array}{l}\text { Nose, throat, and upper } \\
\text { respiratory conditions }\end{array}$ & $\begin{array}{l}\text { Nose, throat, and upper } \\
\text { respiratory conditions }\end{array}$ & $\begin{array}{l}\text { Nose, throat, and uppper } \\
\text { respiratory conditions }\end{array}$ \\
\hline $\begin{array}{l}\text { Viral, bacterial, and } \\
\text { parasitic infections }\end{array}$ & $\begin{array}{l}\text { Injuries (musculoskeletal } \\
\text { and soft tissue, including } \\
\text { back and upper and lower } \\
\text { extremities) }\end{array}$ & Osteoporosis/arthritis & Osteoporosis/arthritis \\
\hline Sexual abuse & $\begin{array}{l}\text { Viral, bacterial, and } \\
\text { parasitic infections }\end{array}$ & Hypertension & Hypertension \\
\hline $\begin{array}{l}\text { Injuries (musculoskeletal } \\
\text { and soft tissue) }\end{array}$ & Acute urinary conditions & $\begin{array}{l}\text { Orthopedic deformities and } \\
\text { impairments (including } \\
\text { back and upper and lower } \\
\text { extremities) }\end{array}$ & Urinary incontinence \\
\hline Acute ear infections & & Heart disease & Heart disease \\
\hline Digestive system conditions & & $\begin{array}{l}\text { Hearing and vision } \\
\text { impairments }\end{array}$ & $\begin{array}{l}\text { Injuries (musculoskeletal } \\
\text { and soft tissue) }\end{array}$ \\
\hline Acute urinary conditions & & & $\begin{array}{l}\text { Hearing and vision } \\
\text { impairments }\end{array}$ \\
\hline
\end{tabular}


mortality is defined as all deaths of women during pregnancy or within one year after the end of pregnancy, regardless of the site or duration of the pregnancy and regardless of the cause of death. This would clear the semantic issues and lead to better case identification and broader understanding of the issues and solutions.

In fact, the developing discipline of women's health demands such a broad understanding of the major causes of mortality and morbidity of all women. This is appropriate since we are not interested in 'just pregnancy' or reproductive health but women's health throughout the life span. This has been recognized by the American College of Obstetricians and Gynecologists as the College has turned its attention to primary and preventive women's health care (Tables 1 and 2) [9]. Many of the diseases recognized as major causes of morbidity have not been addressed in traditional obstetrics and gynecology curricular programs or common practice. They need to be.

It is my hope that this editorial will encourage obstetricians and gynecologists to look at their local environments and identify problems which affect the health care of women and therefore the public health of their communities. In many parts of the developed world, deaths from homicide result from poor socioeconomic conditions, ready access to handguns, and the social consequences of substance abuse. In this last situation, women are often involved as carriers or shields in drug trade, resulting in increased risks of morbidity and mortality. In contrast, burns, and deaths from burns, are major causes of maternal and infant mortality in the Third World, where open cans of inflammable material and floor cooking stoves commonly spill at night in darkness causing major problems for all concerned [10]. Worldwide, $7 \%$ of women with major burns are reportedly pregnant. Public health legislation and support for alternatives to these dangerous products would have far-reaching beneficial effects on the lives of thousands of women and children, regardless of whether they live in the developed or developing worlds.

At my teaching hospital, I notice more and more young students entering our specialty have an increased understanding of the importance of public health. Many have obtained formal education and certification in this field. New training programs with strong support from specialty societies and educational philanthropy are required to develop innovative clinician teachers for medical schools who then will serve as important programmatic resources in the developed and developing world [11]. Prevention and wellness have become important components of modern medical care systems. This is good for our specialty and good for public health. Whereas public health has traditionally been concerned with control of the spread of infectious disease, interdisciplinary teams are now needed to identify significant health problems of women, many of whom are in the reproductive age group. The focus of these teams should be in developing intervention and prevention strategies which can reduce deaths. Potential targets include smoking cessation, wearing seat belts, gun control, reducing exposure to flammable materials, universal access to essential obstetric services for all women, and cancer and heart disease prevention and screening. At the millennium, these are the challenges not only for our specialty but for society.

\section{References}

[1] Rosenfield A, Maine D. Maternal mortality - a neglected tragedy - where is the M in MCH? Lancet July 13, 1985; ii: $83-85$.

[2] Pearlman MD. Motor vehicle crashes, pregnancy loss and preterm labor. Int J Gynecol Obstet 1997;

[3] Berg CJ, Atrash HK, Koonin LM, Tucker M. Pregnancy related mortality inthe United States, 1987-1990. Obstet Gynecol 1996; 88: 161-167.

[4] Atrash HK, Alexander S, Berg CJ. Maternal mortality in developed countries: not just a concern of the past. Obstet Gynccol 1995; 86: 700705.

[5] Pearlman MD, Tintinalli JE, Lorenz RP. Blunt trauma during pregnancy. N Engl J Med 1990; 323: 1609-1613.

[6] Fildes J, Reed L, Jones N, Martin M, Barnett J. Irauma: the leading cause of maternal death. J Trauma 1992; 32 : 64.3-645.

[7] Fratschi S, Cerulli A, Maine D. Suicide during pregnancy and its neglect as a component of maternal mortality. Int J Gynecol Obstet 1994; 47: 275-284.

[8] Sachs BP, Brown DAJ, Driscoll SG, Schulman E, Acker A, Ransil BJ, Jewett JF. Maternal mortality in Massachusetts: trends and prevention. N Engl J Med 1987; 316: $667-672$. 
[9] The Obstetrician-Gynecologist and Primary-Preventive Health Care. Am Coll Obstet Gynecol 1993; 002: 12-13.

[10] Akhtar MA, Mulawkar PM, Kulkarni HR. Burns in pregnancy: effect in maternal and fetal outcomes. Burns 1994; 20: 351-355.
[11] Martey JO, Wilson JB, Adadevoh SWK, Elkins T, Sciarra JJ, MacVicar J. Innovative community-based postgraduate training for obstetrics and gynecology in West Africa. Obstet Gynecol 1995; 85: 1042-1046. 